\title{
PROTOTIPE ROBOT PELAYAN RESTORAN MENGGUNAKAN SENSOR GARIS DENGAN ALGORITMA OPTIMASI LINTASAN
}

\author{
Mirfan \\ mirfan.stmik@handayani.ac.id \\ STIMIK Handayani
}

\begin{abstract}
Abstrak
Penelitian ini bertujuan merancang prototipe robot pelayan restoran menggunakan sensor garis dan sensor pir dengan algoritma optimasi lintasan yang implementasinya disematkan ke dalam mikrokontroller. Metode yang digunakan adalah metode eksprementaal yaitu dengan melakukan perancangan, pembuatan dan pengujian model sistem. Hasil eksperimen menunjukkan bahwa robot pelayan restoran ini dapat bekerja sesuai kemampuan atau daya baterai yang digunakan. Hal ini tidak terdapat pada tenaga kerja manusia yang bekerja secara part time. Cara kerja robot tidak dapat diintervensi oleh perintah lain dari pelanggan seperti panggilan suara atau sentuhan, diketahui akurasi atau ketepatan pada robot lebih baik karena sifatnya yang otomatis. Sebab sifat perintah pada robot sudah diprogram terlebih dahulu, sehingga kesalahan pada penempatan dapat dihindari sebagimana yang biasa terjadi pada tenaga kerja manusia.adalah emosi akibat kelelahan atau kesehatan dan beban pikiran yang menyertai ketika bekerja. Sedangkan pada robot, faktor itu tidak terjadi karena sifatnya yang mekanistik.
\end{abstract}

Kata kunci: Robot, sensor garis ,pelayan restoran.

\section{Pendahuluan}

Perkembangan zaman membuat tuntutan kebutuhan hidup akan pelayanan berubah, kebutuhan serta kesibukan juga meningkat. Manusia dituntut lebih efisien dalam menggunakan waktu untuk memenuhi kebutuhan hidupnya sehingga dapat lebih produktif untuk bekerja. Hal ini membuat banyak usaha jasa yang menyediakan pelayanan pemenuhan kebutuhan manusia bermunculan. Rumah makan merupakan salah satu penyedia barang pemenuhan kebutuhan manusia. Di sebuah rumah makan, terdapat pelayan yang akan memberikan pelayanan kepada pelanggan.

Kinerja pelayan manusia dipengaruhi oleh banyak faktor, antara lain manusia yang masih memiliki rasa lelah dan letih sehingga tidak dapat bekerja secara terus-menerus. Manusia dapat jatuh sakit sehingga tidak dapat melaksanakan tugasnya. Selain itu, manusia juga memiliki rasa jenuh terhadap pekerjaan yang dilakukan secara berulang dalam waktu tertentu dan dilakukan secara terus-menerus. Rasa letih, kejenuhan dan sakit pada manusia dapat mengakibatkan kesalahan kerja. Segala keterbatasan pada manusia yang dapat mengakibatkan kesalahan kerja tersebut menuntut adanya inovasi untuk melakukan efisiensi penggunaan tenaga manusia yang tentunya dapat mengurangi kesalahan kerja dan biaya operasional di suatu rumah makan.

Keterbatasan tenaga manusia yang tidak bisa bekerja secara terus-menerus membuat manusia berpikir untuk melakukan otomasi dalam pengerjaan tugas-tugas yang biasa dikerjakan manusia. Selian itu, otomasi juga diharapkan dapat meningkatkan efisiensi penggunaan tenaga manusia, mengurangi kesalahan kerja dan dapat mengurangi biaya operasional yang harus dikeluarkan. Otomasi yang dapat dilakukan antara lain dengan diciptakannya robot yang tidak mengenal rasa lelah dan tidak dipengaruhi emosi dalam bekerja. Robot ini berfungsi untuk membantu manusia dalam mengerjakan tugas. Robot juga dapat mengurangi kesalahan-kesalahan kerja yang sering dilakukan manusia (human error).

Berdasarkan latar belakang diatas, maka dilakukan penelitian yang berjudul, Prototipe Robot Pelayan Restoran Menggunakan Sensor Garis dan mempunyai lintasan terbatas. Robot ini dirancang dan dibuat untuk dapat mengantar makanan secara otomatis kepada pengunjung restoran, dimana robot ini berjalan dengan mengikuti jalur garis yang telah ditentukan dan dapat mendeteksi keberaadan manusia disekitar meja tamu.

\section{Metode}

Robot adalah sesuatu yang dapat di program dan diprogram ulang, dengan memiliki manipulator mekanik / pengerak yang didesain untuk memindahkan barang-barang, komponen-komponen atau 
ILKOM Jurnal Ilmiah Volume 9 Nomor 1 April 2017

alat-alat khusus dengan berbagai program yang fleksibel / mudah disesuaikan untuk melaksanakan berbagai macam tugas.

Pada perancangan ini terdapat beberapa komponen yang saling berkaitan serta saling mendukung dan membentuk sebuah rangkaian sistem prototipe robot pelayan restoran menggunakan sensor garis dan sensor PIR. Adapun komponen-komponen utama yang membangun sistem ini adalah media input berupa sensor garis, sensor PIR dan Tombol.

\subsection{Sensor Garis}

Sensor garis yang biasanya di gunakan pada Robot Line Follower, Ada banyak pilihan untuk sensor ini, Mulai dari yang paling sederhana menggunakan LDR, Phototransistor, Photodiode, sampai menggunakan Photoreflector". Sensor garis atau proxymity sensor adalah sensor yang berfungsi mendeteksi warna gelap atau warna terang, dimana warna gelap atau terang tersebut terdeteksi akibat pantulan cahaya lampu (biasanya menggunakan lampu LED) yang terdapat pada sensor. [1]

\subsection{Light Dependet Resistor (LDR)}

LDR foto resistor telah banyak di gunakan dalam beberapa tahun ini. Komponen yang satu ini di bentuk sejak awal abad kesembilan belas ketika konduktivitas akan selenium di temukan oleh Smith pada tahun 1873. Sejak saat itu lah di mulai pembuatan beberapa perangkat mulai berkembang. Zat lain yang terdapat pada komponen ini adalah $\mathrm{PbS}, \mathrm{PbSe}$ dan $\mathrm{PbTe}$ yang di pelajari di tahun 1930 dan 1940. Kemudian pada tahun 1952, Rollin dan Simmons mengembangkan LDR menggunakan silikon dan germanuim. Rangkaian LDR atau Light Dependent Resistor adalah salah satu komponen elektronika yang masih bisa di bilang sebagai resistor yang besar resistasi nilai tahanannya bergantung pada intensitas cahaya yang menutupi permukaan. Rangkaian LDR biasanya di kenal dengan nama foto resistor, foto konduktor, sel foto konduktif atau komponen lain yang sering di gunakan dalam literatur suatu rangkaian. Itu sebabnya makin kuat intensitas cahaya maka makin kecil nilai tahanannya dan makin lemah intensitas cahaya maka makin besar nilai tahanannya.

Komponen LDR di buat dari Cadmium Sulphide (CdS). Pada umumnya, rangkaian LDR di gunakan sebagai sensor cahaya. LDR akan padam pada saat LDR mendapat cahaya cukup terang, apabila LDR tidak mendapat cahaya maka komponen ini akan menyala[2].

\subsection{Sensor PIR}

PIR (Passive Infrared Receiver) merupakan sebuah sensor berbasiskan infrared. Akan tetapi, tidak seperti sensor infrared kebanyakan yang terdiri dari IR LED dan fototransistor. PIR tidak memancarkan apapun seperti IR LED. Sesuai dengan namanya'Passive', sensor ini hanya merespon energi dari pancaran sinar inframerah pasif yang dimiliki oleh setiap benda yang terdeteksi olehnya. Benda yang bisa dideteksi oleh sensor ini biasanya adalah tubuh manusia.

\subsection{Mikrokontroler}

Mikrokontroler adalah mikroprosessor yang dirancang khusus untuk aplikasi kontrol, dan dilengkapi dengan ROM, RAM dan fasilitas I/O pada satu chip [3]. AT89S52 adalah salah satu anggota dari keluarga MCS-51/52. AT89S52 dirancang oleh Atmel sesuai dengan instruksi standar dan susunan pin 80C5. Mikrokontroler 89552 merupakan versi terbaru dibandingkan mikrokontroler AT89C51 yang telah banyak digunakan saat ini. Mikrokontroler merupakan sebuah sistem komputer yang seluruh atau sebagian besar elemennya dikemas dalam satu chip IC, sehingga sering disebut Single Chip Microcomputer. Mikrokontroler merupakan sebuah sistem komputer yang mempunyai satu atau beberapa tugas yang sangat spesifik, berbeda dengan PC ( personal Computer) yang memiliki beragam fungsi. Perbedaan yang lainnya adalah perbandingan RAM dan ROM yang sangat berbeda antara komputer dengan mikrokontroler. Dalam mikrokontroler ROM jauh lebih besar dibanding RAM, sedangkan dalam komputer atau PC, RAM jauh lebih besar dibanding ROM [4].

\subsection{Software}

\subsection{1 .Bahasa Bascom}

Pada pernelitian ini menggunakan bahasa BASCOM-8051. Bahasa BASCOM-8051 merupakan bahasa basic. Bahasa Basic adalah bahasa pemrograman yang dapat dikatakan berada di antara bahasa tingkat rendah dan tingkat tinggi. Bahasa tingkat rendah artinya bahasa yang berorientasi pada mesin dan tingkat tinggi berorientasi pada manusia. Bahasa tingkat rendah, misalnya bahasa assembler, bahasa ini ditulis dengan sandi yang dimengerti oleh mesin saja, oleh karena itu hanya digunakan bagi yang memprogram mikroprosesor. Bahasa tingkat rendah merupakan bahasa yang membutuhkan kecermatan yang teliti bagi pemrogram karena perintahnya harus rinci, ditambah lagi masing-masing pabrik mempunyai sandi perintah sendiri. Bahasa tinggi relatif mudah digunakan, karena ditulis dengan bahasa manusia sehingga mudah 


\section{ILKOM Jurnal Ilmiah Volume 9 Nomor 1 April 2017}

dimengerti dan tidak tergantung mesinnya. Bahasa tingkat tinggi biasanya digunakan pada komputer.

\subsubsection{Algoritma Optimasi Lintasan}

Untuk lintasan, robot menggunakan prinsip sederhana algoritma optimasi lintasan yaitu prinsip antrian (antrian tak berprioritas), page yang masuk lebih dulu maka akan keluar lebih dulu juga. Algoritma ini menggunakan struktur data stack. Apabila tidak ada frame kosong saat terjadi page fault, maka yang dipilih adalah frame yang berada di stack paling bawah, yaitu halaman yang berada paling lama berada di memori. Dengan hanya informasi mengenai lama berada di memori, maka algoritma ini dapat memindahkan page yang sering digunakan. Boleh jadi page itu berada terus di memori karena selalu digunakan. Page itu karena mengikuti pola antrian berdasar lamanya berada di memori menjadi elemen terdepan, diganti, dan segera harus masuk kembali ke memori sehingga terjadi page fault kembali.[5]

Pada perancangan ini terdapat beberapa komponen yang saling berkaitan serta saling mendukung dan membentuk sebuah rangkaian sistem prototipe robot pelayan restoran. Adapun komponen-komponen utama yang membangun sistem ini adalah media input,media proses dan media output. Media input berupa tombol dan dua sensor yakni sensor garis dan sensor PIR serta sensor LDR untuk limit switch. Media proses yang digunakan adalah komparator dan Mikorokontroller AT89S52.

Kedua sensor tersebut memiliki fungsinya masing-masing dalam menerima input. Sensor garis berfungsi untuk mendeteksi lintasan robot dengan cara membedakan warna saat mengantarkan pesanan. Dalam hal ini, lintasan garis yang dilalui berwarna hitam. Sensor garis Sedangkan sensor PIR yang merupakan sensor yang peka terhadap suhu berfungsi untuk mendeteksi manusia atau benda lainnya yang berada di sekitar robot baik itu yang berada di luar lintasan maupun yang berada di di dalam lintasan yang dapat menghalangi robot saat bertugas mengantarkan pesanan. Selain kedua sensor tersebut, robot memanfaatkan komponen LDR sebagai limit switch untuk mendeteksi setiap pesanan yang diletakkan diatas nampan apakah sudah sudah sampai pada pemesan. Dengan adanya limit switch ini, robot akan secara otomatis kembali ke meja koki apabila semua pesanan telah sampai pada mejanya masing-masing.

Komparator berfungsi untuk mengubah sinyal analog dari sensor menjadi sinyal digital yang dapat dikenali oleh mikrokontroler. Mikrokontroler AT89S52 yang telah disematkan algoritma optimasi lintasan berfungsi sebagai pusat control robot dimana program yang digunakan adalah bahasa Assembly. Output dari robot ini adalah gerak roda. Gerak motor robot di kontrol oleh driver motor. Adapun arsitektur sistem prototipe robot pelayan restoran menggunakan sensor garis dapat dilihat pada gambar 1 berikut ini :

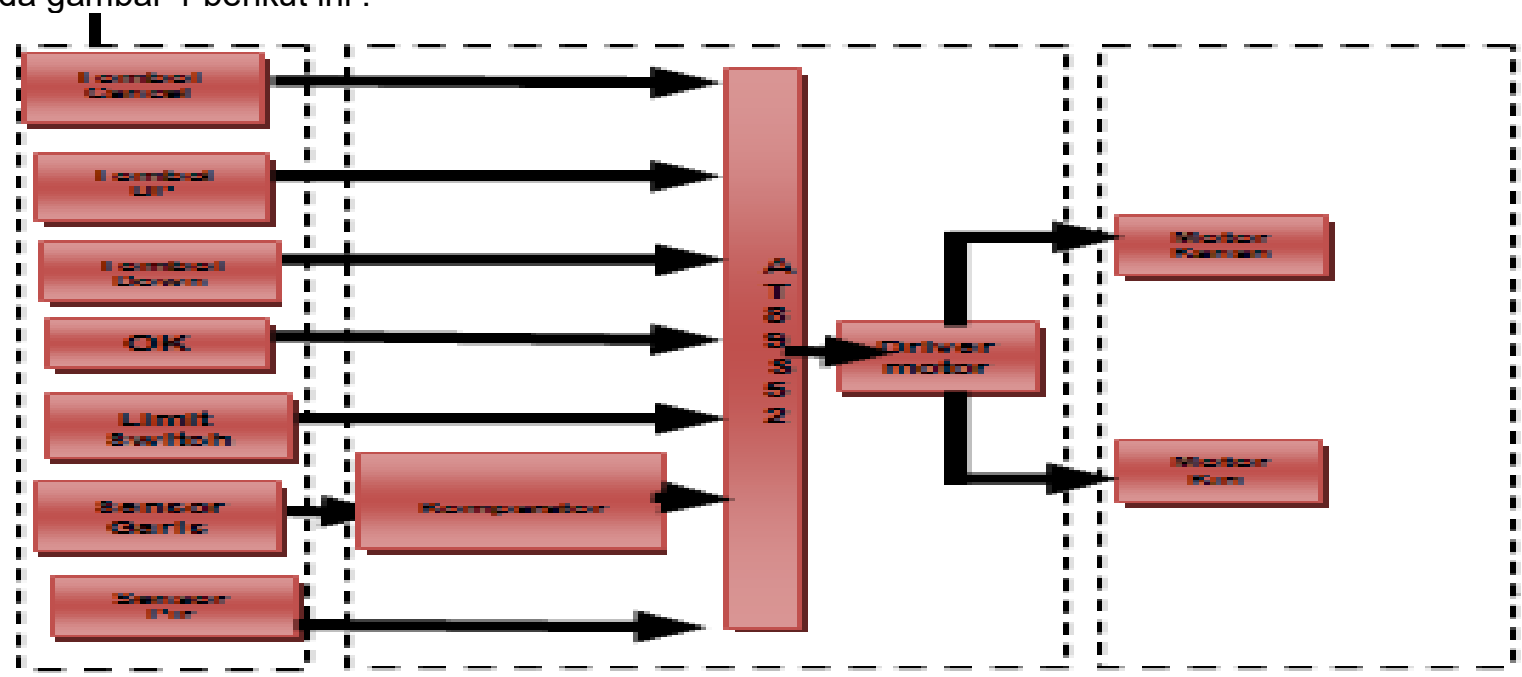

Gambar 1. Diagram blok rangkaian robot pelayan restoran

\section{Hasil dan Pembahasan}

Hasil dari pengujian ini adalah perancangan dan pembuatan prototype robot pelayan restoran yang digunakan untuk melakukan pengantaran makanan kepada meja pelanggan. Robot bekerja berdasarkan input yang diberikan sehingga dapat mengantar makanan melalui lintasan yang berwarna hitam. Robot ini terbuat dari bahan aluminium berbentuk persegi, dengan panjang $49 \mathrm{~cm}$, lebar $40 \mathrm{~cm}$, dan tinggi $84 \mathrm{~cm}$. Desain robot ini terdiri dari tiga tingkat, dimana tingkat pertama 
ILKOM Jurnal Ilmiah Volume 9 Nomor 1 April 2017

digunakan untuk nampan pesanan meja pertama, tingkat dua untuk nampan pesanan meja dua, dan tingkat tiga untuk nampan pesanan meja tiga. Pada bagian atas setiap lantai terdapat limit switch yang berfungsi sebagai pendeteksi bagi robot bahwa pelanggan telah mengambil pesanan ataukah belum. Sedangkan sensor PIR berfungsi untuk mendeteksi jika ada hambatan dilintasan robot. Adapun sensor proximity berfungsi untuk membaca lintasan dengan menggunakan LED yang dihubungkan kemikrokontroller. Pada bagian belakang robot dilengkapi dengan tombol on/off yang berguna untuk mengaktifkan robot. Sedangkan layar LCD untuk memberikan informasi mengenai intruksi yang sedang dikerjakan oleh robot kepada pelayan restoran. dapat dilihat pada gambar 2 berikut :

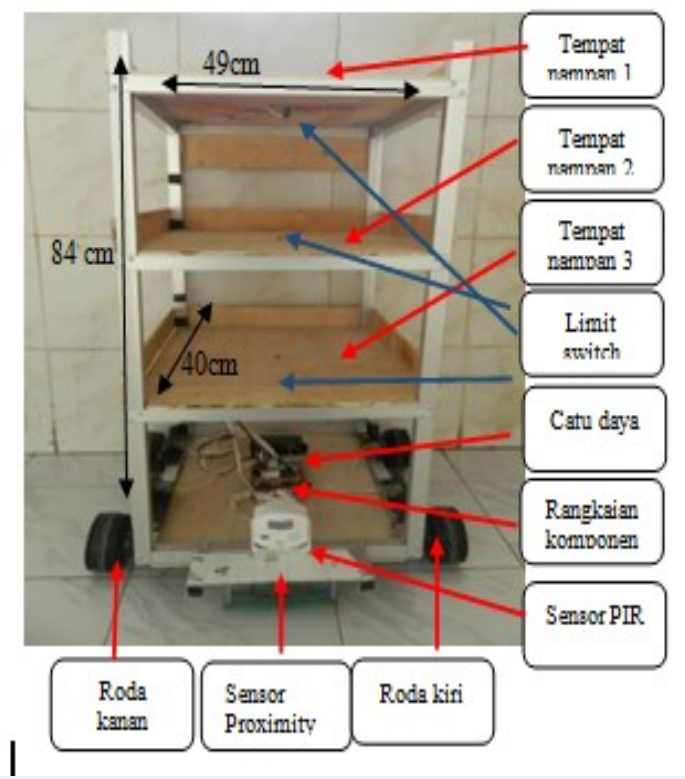

Gambar 2. Robot pelayan restoran Tampak dari depan

Pada pengujian robot secara keseluruhan dilakukan pada lintasan dengan tujuan untuk mengetahui bagaimana kinerja dari robot tersebut dalam mengantarkan makanan sesuai perintah. Dalam hal ini penulis melakukan pengujian 3 buah meja dalam 5 lintasan dengan menggunakan pushbutton sebagai inputnya dan LCD sebagai penampil menu untuk pilihan lintasannya. Apabila pesanan akan diantarkan ke meja 1 maka koki menekan push button up atau down untuk menemukan menu lintasan meja 1 yang dapat dilihat pada LCD. Bila menu lintasan telah ditemukan lalu tekan push button ok maka robot akan melalui lintasan yang telah diprogramkan. Apabila pesanan telah diantarkan maka robot akan berputar kembali ke meja koki. Koki akan menekan push button reset lalu memasukkan perintah pesanan selanjutnya.dapat dilihat pada gambar 3 berikut :

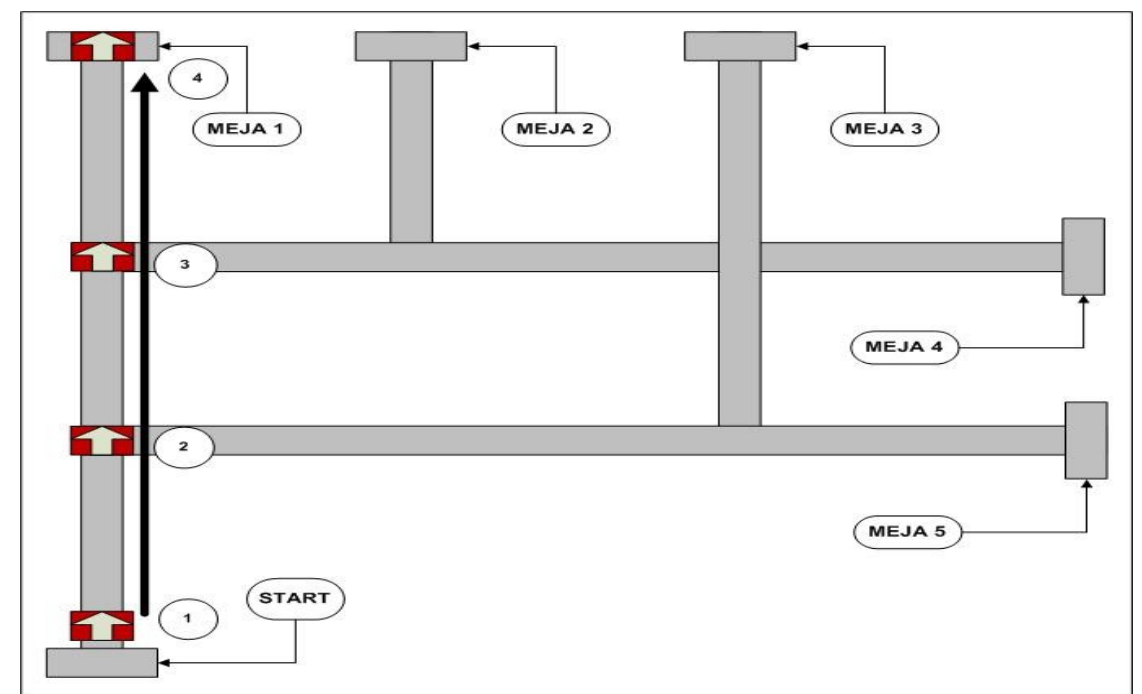

Gambar 3. Robot menuju ke meja 1 
Apabila terdapat pesanan untuk 3 meja sekaligus, koki menekan push button up atau down untuk menemukan pilihan menu meja 1,3 dan 5 lalu menekan push button ok. Maka robot akan menuju meja 1 terlebih dahulu kemudian berputar mengikuti lintasan menuju meja 3 . Dari meja 3, robot kembali berputar menuju meja 5 . Setelah ketiga makanan diantarkan dan diambil oleh pemesan, maka robot berputar dan kembali menuju meja koki melalui lintasan yang sesuai dengan menu lintasan yang telah dipilih. dapat dilihat pada gambar 4.

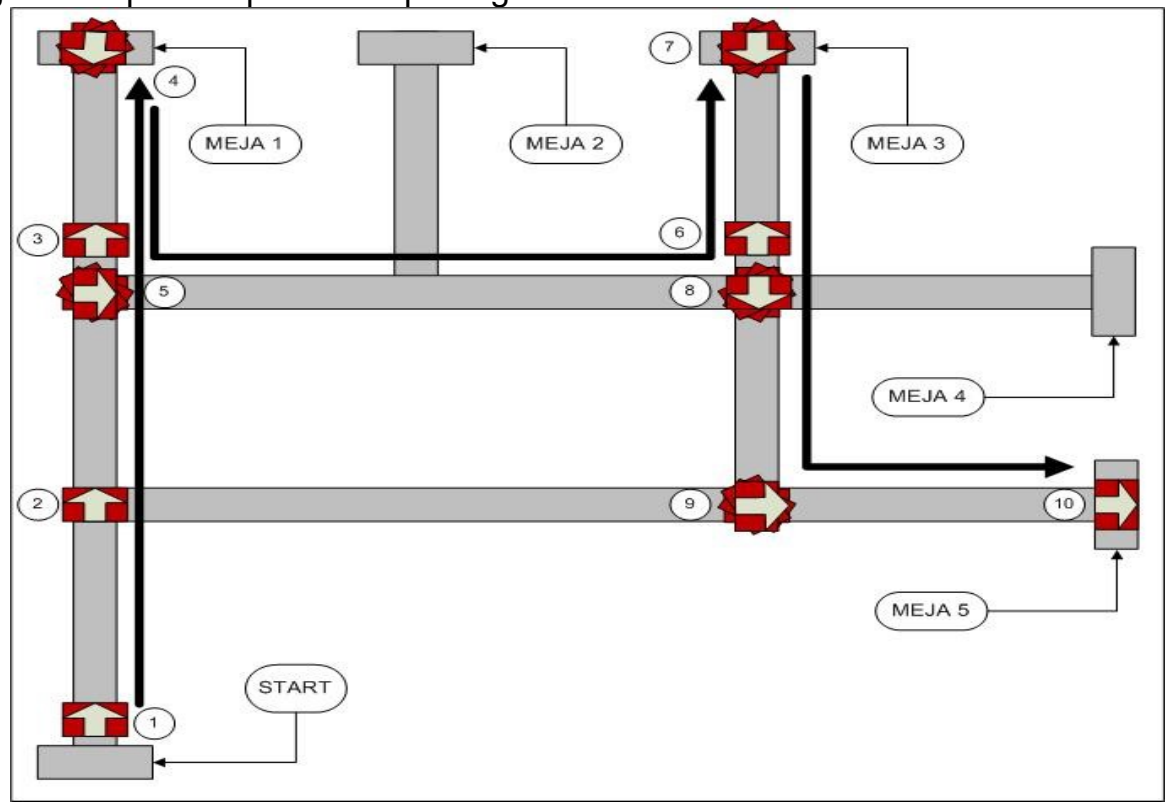

Gambar 4. Robot Star menuju ke meja 1,3 dan 5

\section{Kesimpulan dan saran}

Berdasarkan hasil pengujian algoritma pada robot, maka kesimpulan yang dapat diperoleh dalam penelitian ini adalah mendapatkan lintasan terbaik yang dapat dilalui oleh robot pelayan restoran. Algoritma yang diterapkan membuat robot melalui lintasan yang tidak redundan dan dapat menghemat daya dan waktu dalam implementasinya. Disamping itu, sistem kerja di restoran dalam pelayanan terhadap pelanggan dapat menjadi lebih mudah dan robot pelayan restoran merupakan teknologi dan inovasi baru di Indonesia sehingga pengunjung dapat menarik pengunjung.

Robot Line Follower dapat menjadi terobosan baru yang diterapkan dalam kehidupan sehari-hari untuk mengefisienkan pekerjaan manusia. Terutama untuk pekerjaan yang membutuhkan konsentrasi serta ketepatan dalam proses pengerjaannya.

\section{Daftar Pustaka}

[1] Sugiharto,Agus. Penerapan Dasar Transducer dan Sensor. Yogyakarta : Perpustakaan FMIPA UGM,2010.

[2] S.T.D. Septian. Build your Own Line Follower Robot. Yogyakarta:Penerbit Andi,2008.

[3] Atmel. Data sheet Mikrokontroller. Yogyakarta : Penerbit Andi,2010

[4] Miller Peter."Building a Two Wheeled Balancing Robot", University of Southern Queensland, Faculty of Engineering and Surveying, 2008.

[5] Miller Peter."Building a Two Wheeled Balancing Robot”, University of Southern Queensland, Faculty of Engineering and Surveying,2008. 